\title{
STUDY OF EXHAUST EMISSIONS REDUCTION OF A DIESEL FUEL OPERATED HEATER DURING TRANSIENT MODE OF OPERATION
}

\section{L'UBOMÍR MIKLÁNEK, ONDŘEJ GOTFRÝD}

Josef Božek Vehicle Centre for Sustainable Mobility, Czech Technical University in Prague, Czech Republic Tel.: +420 224351 855, +420 246003 709, E-mail: lubomir.miklanek@fs.cvut.cz, ondrej.gotfryd@fs.cvut.cz

\section{SHRNUTI}

Naftová nezávislá topení se obecně používají jako nezávislý zdroj tepla kdekoliv, kde je k dispozici zdroj nafty a elektrické energie. Vzhledem k faktu, že účinnost budoucích spalovacích motorů se bude zvyšovat a pro ohřev prostoru pro cestující tak zbude k dispozici ještě méně tzv. odpadního tepla, význam nezávislých zdrojů tepla dál poroste.

Současné emisní prèedpisy pro nezávislá topení nejsou v Evropě natolik prísná, jako emisní předpisy pro spalovací motory. Předpisy se týkají emisí ve výfukových plynech pouze v tzv. ustálených režimech, nikoli v režimech prechodových, jako je studený start a vypnutí topení.

A právě ve zmiňovaných dvou přechodových režimech konvenčního typu nezávislého naftového topení dochází k razantnímu nárůstu emisí CO, $\mathrm{HC}$ a také kouřivosti (především emisí bílého kouře).

Obsahem tohoto článku je studie možných řešení, použitelných pro nezávislá naftová topení s cílem eliminovat zvýšené emise škodlivin a také kouře během studeného startu a vypínání topení.

KLIČCOVÁ SLOVA: SNIŽOVÁNÍ EMISÍ, NEZÁVISLÝ ZDROJ TEPLA, STUDENÝ START TOPENII, VYPÍNÁNÍ TOPENÍ

\section{ABSTRACT}

Diesel fuel operated heaters (FOHs) are generally used as an independent heat source for any system in which a diesel fuel and battery power is available. Based on the fact that future engines will become even more efficient and thus less waste heat will be available to heat the passenger compartment, independent heat sources will be even more necessary.

Current emissions limits for diesel FOHs in Europe are not as strict as the engine emissions limits. There are only limited exhaust emissions at steady-state operating regimes of a heater, although not at both cold-start and switching-off regimes. However, it can be assumed that these emissions limits will become stricter with the increasing number of independent FOHs. Thus exhaust emissions at the both cold-start and switching-off regimes will also be established.

Increased emissions of $\mathrm{CO}, \mathrm{HC}$ and also smoke (especially white smoke emissions) appears at the both cold-start and switching-off regimes in the case of a conventional $\mathrm{FOH}$ design. The emission limits for steady-state regimes can be exceeded several times at these two unsteady regimes. In order to solve this issue, it will be necessary to find a solution for elimination of increased exhaust emissions. The content of this paper is a theoretical study of possible solutions and ways to obtain a reduction in the increased exhaust emissions of conventional FOH designs at both cold-start and switching-off regimes. Several proposed means are investigated in this study. Their ability to eliminate increased emissions (also of white smoke) is evaluated in the conclusion.

KEYWORDS: EMISSIONS REDUCTION, INDEPENDED HEAT SOURCE, COLD-START OF DIESEL-HEATER, DIESEL-HEATER SWITCHING-OFF

\section{INTRODUCTION}

Based on the results of various studies, the fuel operated heaters (diesel, gasoline or gas) appear the best solution for independent devices to heat up air in the passenger compartment or liquid in a cooling system of a vehicle, [1], [2] and [3].

Moreover, it can be assumed that emissions limits for independent heaters will become ever stricter with the increasing number of heaters. Currently, the emissions of independent conventional FOHs at steady-state regimes are very low. However, decreasing emissions at unsteady-state regimes, especially at both coldstart and switching-off, is still a challenge. The content of the article is a theoretical study of several proposed solutions to decrease high values of emissions of FOHs during the mentioned unsteady-state regimes. This study mainly concerns solutions for diesel fuel operated air heaters (FOAHs) to heat up the air in a passenger cab. The identified solutions will also be applicable for diesel fuel operated coolant heaters (FOCHs). 


\section{OVERVIEW OF CONVENTIONAL DIESELFOHS}

A simple view inside a conventional diesel FOAH is shown in Figure 1, based on data from a manufacturer [4].

As can be seen in Figure 1, combustion-air is forced into the combustion chamber by a combustion-air fan. A glow plug is applied in the combustion chamber as a heat source. An evaporating element can be installed close to the glow plug in order to provide enough heat for fuel evaporation and ignition after heating up of the combustion chamber. Thus, the glow plug need operate only during the cold-start.

Fuel is transported into the combustion chamber using a solenoid fuel metering pump, which means a low-pressure fuel system implementation. Fuel is fed to the evaporating element close to the glow plug.

During cold-start, the glow plug is first heated. After sufficient heating up of the glow plug, combustion-air is then fed into the combustion chamber. Simultaneously, fuel is fed to the evaporating element close to the glow plug. The fuel is evaporated and mixed with air under sufficient heat conditions. The air-fuel mixture is then ignited using heat radiation from a heat source. Burned mixture - exhaust gas - flows around the flame monitoring and overheating sensor, see Figure 1. The exhaust gas then flows outside of the combustion chamber along the ribs of the heat exchanger (marked as convector in Figure 1). Thus, the heat exchanger (air/exhaust gas type) is heated up. Exhaust gas finally flows to the outlet and to the exhaust pipe.

The combustion-air fan is placed on the same electric motor axle as the heating-air fan wheel, see Figure 1. This means that both combustion-air and heating-air flow simultaneously through the system. Thus, it is not possible to heat up the heat exchanger (using the hot exhaust gas) without any heating-air flow at the opposite side of the heat exchanger. This solution allows not only compact heater dimensions, but it also has a safety function.

To protect the FOAH against overheating, an overheating sensor is placed on the heat exchanger, as shown in Figure 1. In the event of exceeding the temperature limit of the heat exchanger, fuel supply is cut off and only the fan motor is operated. In this way, the FOAH is cooled down due to the air flow through the combustion chamber and simultaneously through the heat exchanger.

As shown in Figure 1, combustion-air is not fed into the combustion chamber from the heating-air flow downstream of the fan wheel. This solution allows both more heating-air to be brought to the heat exchanger and also for combustion-air to be obtained from another source than the heating-air.
A diesel $\mathrm{FOCH}$ is in principle very similar to a diesel FOAH. A view inside a conventional diesel $\mathrm{FOCH}$ is shown in Figure 2, according to [4].

A comparison of Figure 1 and Figure 2 shows the differences between these two types of heater. The diesel FOCH does not need a heating-air fan wheel. Instead of this a coolant pump should be used. And of course, instead of heating-air, the coolant (water) is heated in the heat exchanger. Thus, the heat exchanger is a water/exhaust gas type.

As visible in both Figures 1 and 2, exhaust emissions (also smoke) are created in the combustion chamber. Thus, to avoid creation of increased exhaust emissions during both cold-start

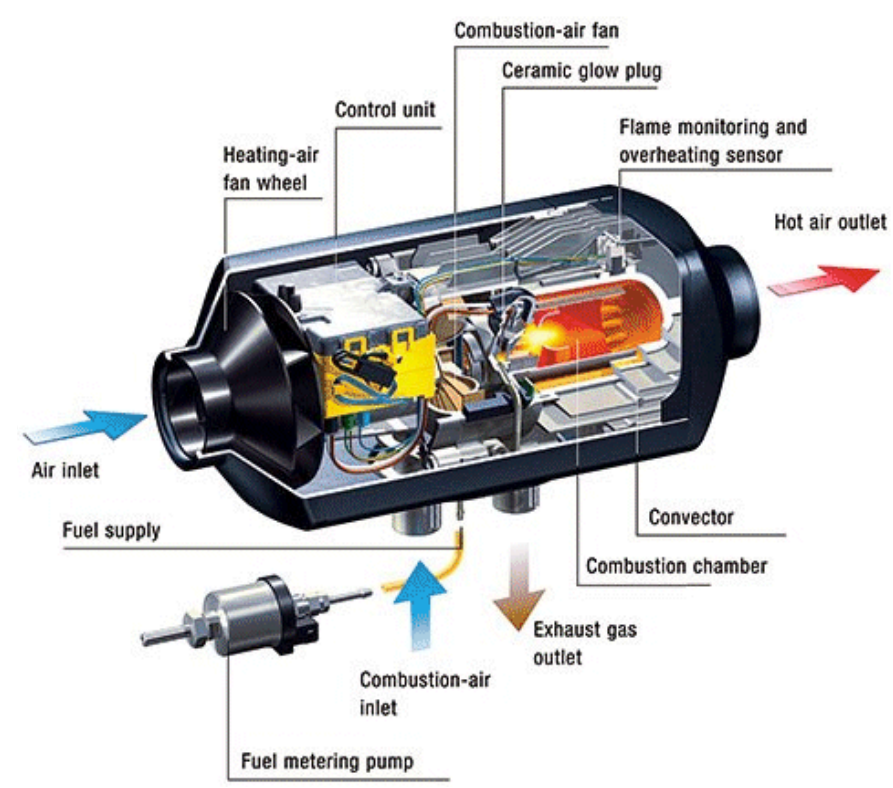

FIGURE 1: View inside a conventional diesel FOAH, [4]. OBRÁZEK 1: Pohled dovnitř konvenčního naftového topení pro ohřev vzduchu (FOAH), [4].

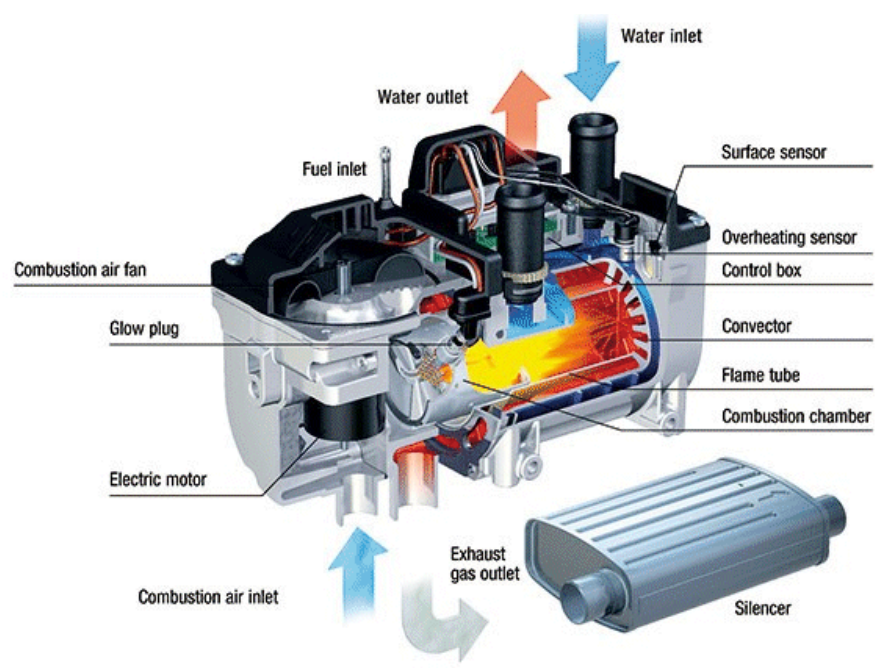

FIGURE 2: View inside a conventional diesel FOCH, [4]. OBRÁZEK 2: Pohled dovnitř konvenčního naftového topení pro ohřev kapaliny (FOCH), [4]. 
and switching-off regimes, it is necessary to find solutions which enable an enhanced quality of fuel combustion in the combustion chamber during the mentioned regimes.

\section{MEASURED DATA OF EMISSIONS}

In order to investigate exhaust emissions of the diesel $\mathrm{FOH}$ at both unsteady and steady-state regimes, a sample of a conventional FOAH was tested in the authors' laboratory. The working principle of this diesel heater type corresponds to Figure 1.

Exhaust emissions ( $\mathrm{CO}, \mathrm{HC}$ and $\mathrm{NO}$ ) were measured using a set of laboratory Non Disperse Infrared Analyzers (NDIR), from the company $A B B$, [5]. Opacity (which was used for smoke measurements) was measured with an Opacimeter. This instrument was part of a mobile set of analyzers, see [6]. To measure content of $\mathrm{HC}$, an analyzer (NDIR) calibrated using Hexane was applied. A Total HydroCarbons (THC) analyzer was unfortunately not available at the time of experimental works.

A test rig for a diesel FOAH was equipped with a DAQ system for acquisition of slowly changing time-based quantities. Thus, measured data were acquired using this DAQ system, see works [7] and [8].

Emissions were measured in all the operating regimes (12), i.e. cold-start, heating and switching-off (also marked Stop). This type of FOAH is equipped with 10 heating modes, where power level of " 0 " corresponds to the least power output and power level of " 9 " corresponds to the maximum power output.

To protect know-how of the heater's manufacturer, measured values of emissions were normalized using the highest measured value of the particular pollutant. Only normalized values of emissions are presented in the Figures below.

Measured normalized values of opacity (smoke) and HC (Hexane) are presented in Figure 3. As shown in this Figure, maximum

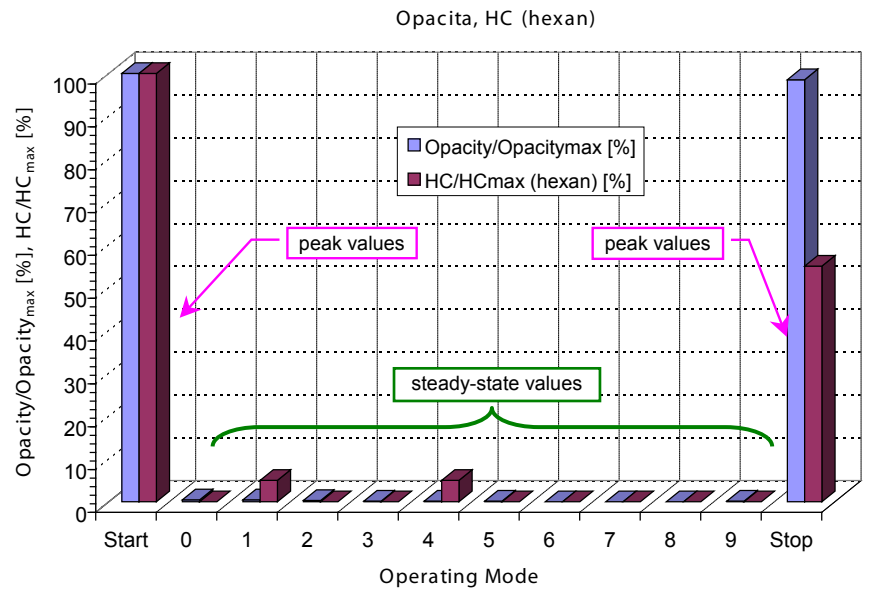

FIGURE 3: Normalized measured values of HC emissions (Hexane) and Opacity in all measured regimes.

OBRÁZEK 3: Normalizované hodnoty naměřených emisí HC (Hexan) a Opacity ve všech režimech. values of smoke appear at both cold-start and switching-off (Stop) regimes. In these two regimes, measured values are changing over time. This is why maximum values are taken into account. However, measured values in other regimes are steadystate. Furthermore, maximum values of $\mathrm{HC}$ are detected in both the regimes with maximum values of smoke, as expected. On the other hand, measured values of emissions are very low in steady state regimes (0 to 9 ).

Similarly to $\mathrm{HC}$, maximum values of emissions of $\mathrm{CO}$ are observed at the same regimes (both cold-start and switching-off), as expected, see Figure 4. On the other hand, measured values of $\mathrm{NO}$ are minimum in both cold-start and switching-off regimes. However, maximum values of NO are observed in the regime where the best conditions for the creation of $\mathrm{NO}$ are achieved in the combustion chamber (mode 7 in this case). Low values of NO in both regimes Start and Stop indicate a low temperature in the combustion chamber.

Thus, increased values of emissions of $\mathrm{HC}, \mathrm{CO}$ and smoke are formed under lower temperature conditions in the combustion chamber (at both cold-start and switching-off regimes).

For better understanding of smoke in exhaust gas of FOAH during both the cold-start and switching-off regimes, white smoke was observed against a black background. Photos of this experiment are presented in the Figures below.

Visible white smoke from the FOAH exhaust pipe during the cold-start procedure is presented in Figure 5 . This white smoke appeared for about $4-5$ seconds.

Visible white smoke from $\mathrm{FOAH}$ exhaust pipe during the switching-off procedure is presented in Figure 6 . White smoke appeared for about 19-20 seconds.

It is necessary to point out that both the unsteady regimes (coldstart and switching-off) work with evaporated but not burned fuel.

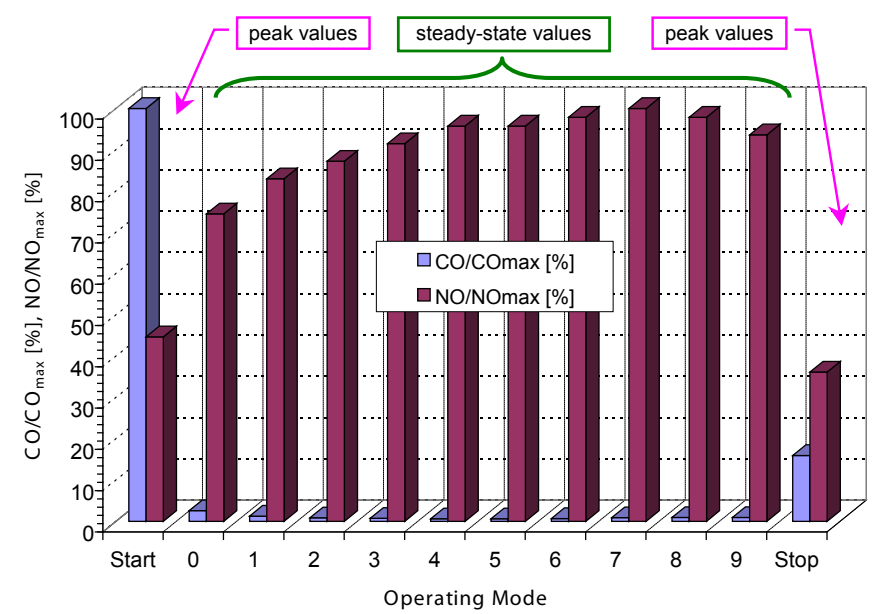

FIGURE 4: Normalized measured values of emissions of CO and NO in all measured regimes.

OBRÁZEK 4: Normalizované hodnoty naměřených emisí CO a NO ve všech režimech

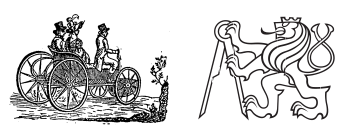




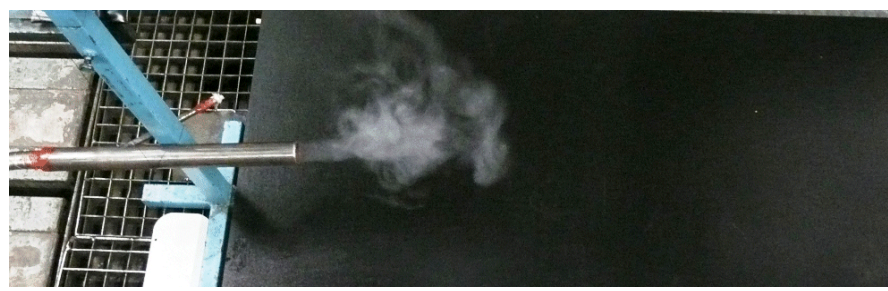

FIGURE 5: Visible white smoke in exhaust gas during the cold-start. OBRÁZEK 5: Viditelný bílý kouř ve výfukových plynech během studeného startu topení.

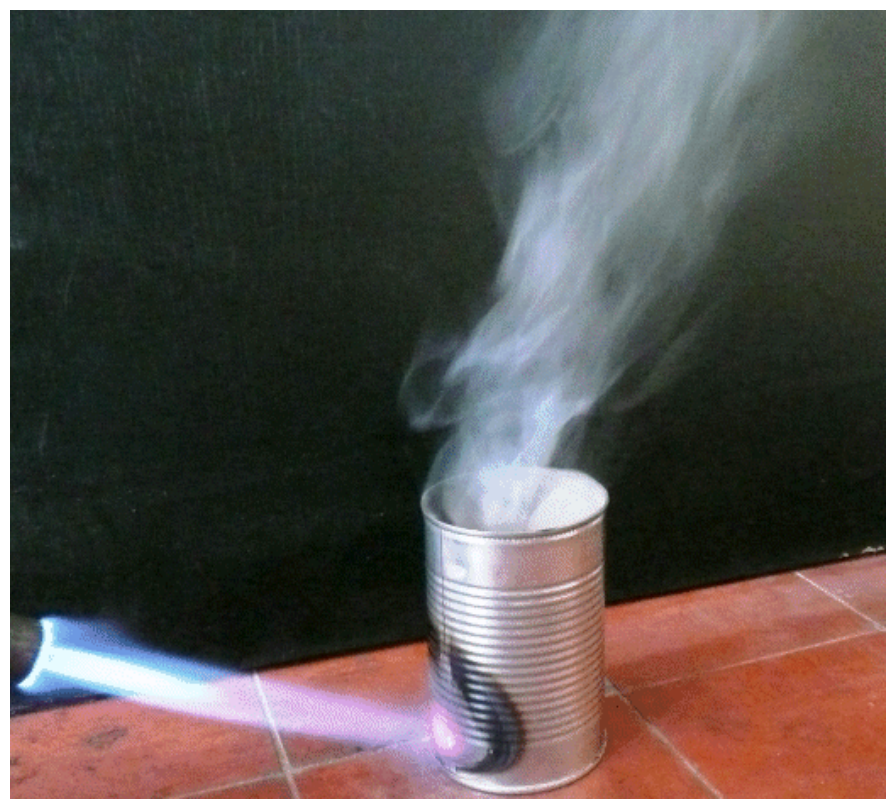

FIGURE 7: Heating of the experimental tin using the gas burner to obtain fuel evaporation.

OBRÁZEK 7: Ohřev experimentální nádoby plynovým hořákem pro dosažení odpařování paliva.

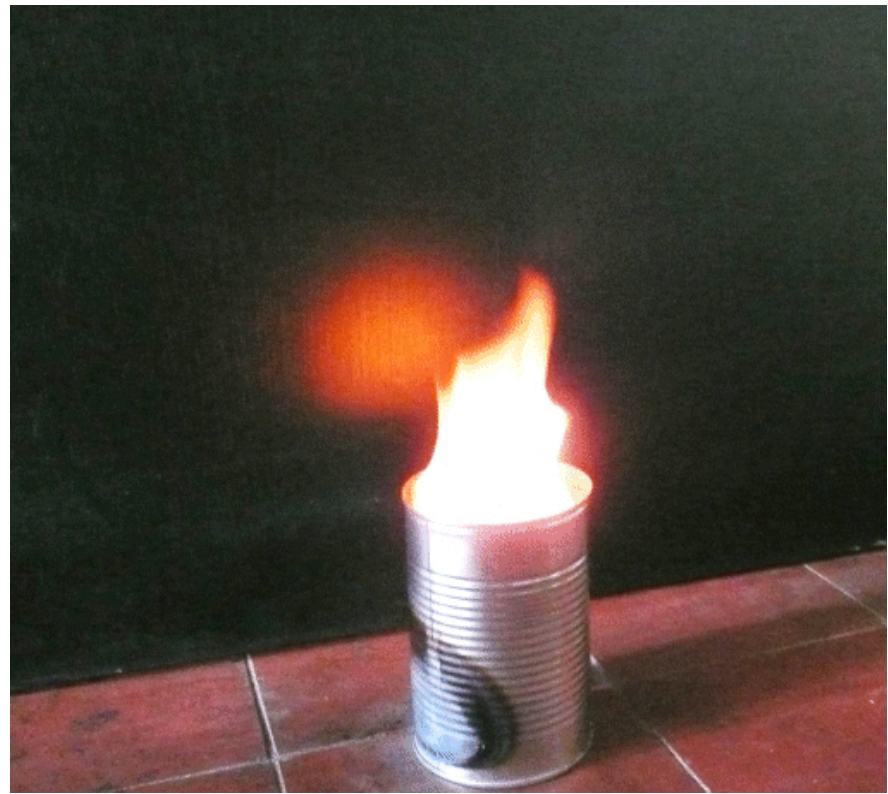

FIGURE 9: Burning of the evaporated diesel fuel in the experimental tin. OBRÁZEK 9: Hoření odpařené nafty v experimentální nádobě.

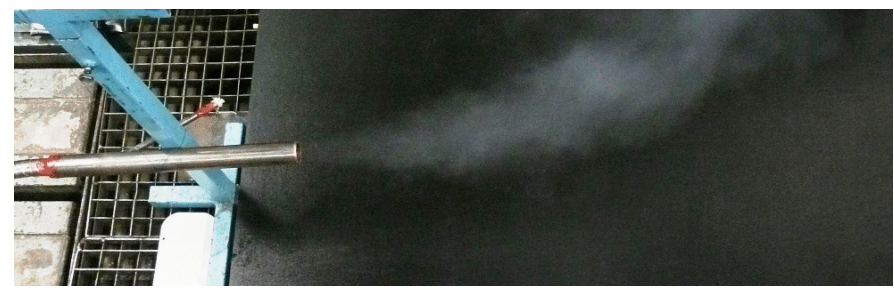

FIGURE 6: Visible white smoke in exhaust gas during the switching-off. OBRÁZEK 6: Viditelný bílý kouř ve výfukových plynech během vypínání topení.

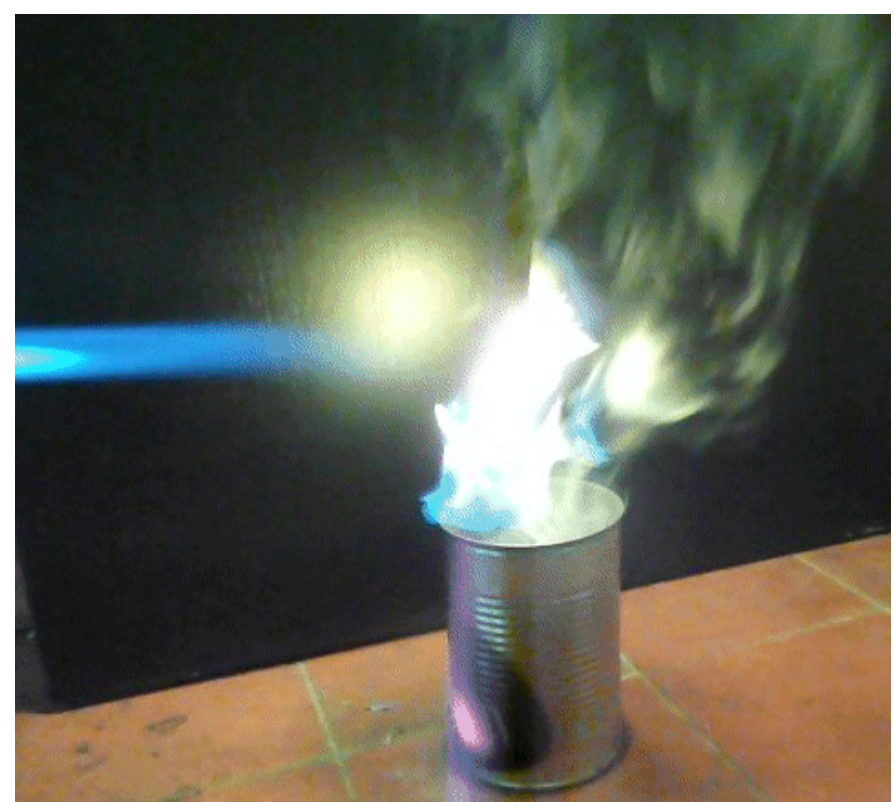

FIGURE 8: Start of burning of the evaporated diesel fuel in the experimental tin.

OBRÁZEK 8: Zapálení odpařené nafty nad experimentální nádobou.

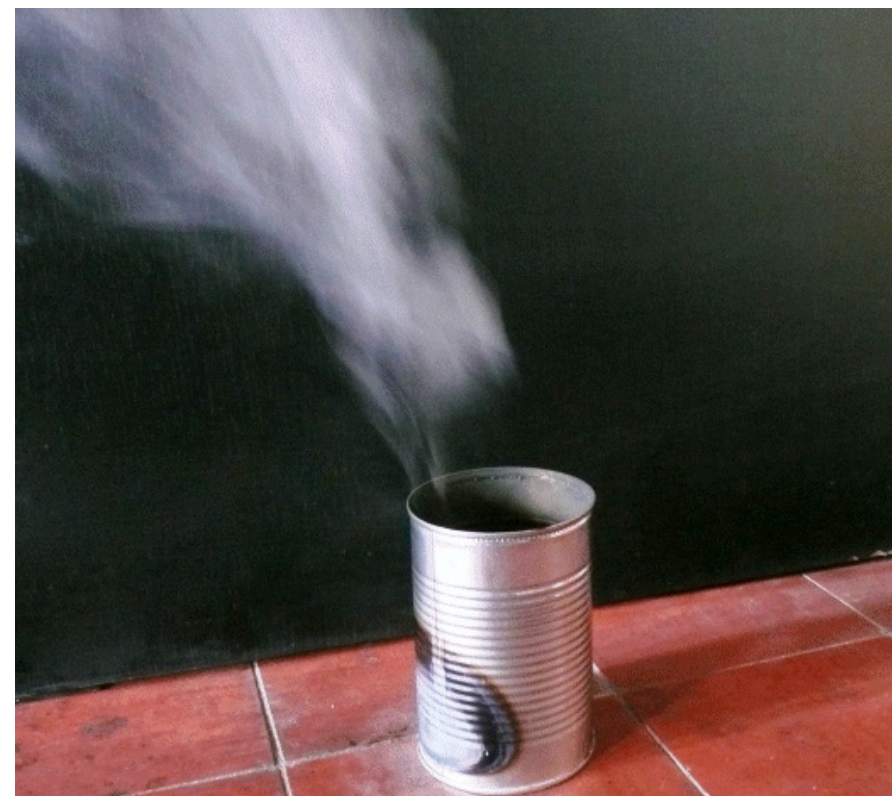

FIGURE 10: White smoke over the experimental tin after the flame extinction. OBRÁZEK 10: Bílý kouř nad experimentální nádobou po zhasnutí plamene. 
Based on this fact, experimental investigation was realized in order to determine the reasons for white smoke formation, as follows.

\section{INVESTIGATION OF WHITE SMOKE FORMATION}

To understand the reasons why both white smoke and increased emissions form at both the mentioned unsteady regimes, a simple experiment was conducted. Evaporation of fuel and its burning took place during this experiment. Fuel evaporation was performed in an experimental tin. Heating of the fuel was achieved using a gas burner. Conventional diesel fuel for cars was used.

A small amount of diesel fuel (about $7 \mathrm{ml}$ ) was heated in an experimental tin using the gas burner until the fuel was evaporated. The aim was to simulate conditions of fuel evaporation in the combustion chamber of an $\mathrm{FOH}$. As is visible in Figure 7, white smoke was formed as a consequence of fuel evaporation.

More and more white smoke was formed with continuation of heating of the experimental tin. However, no flame was developed in the experimental tin in this way of heating of the tin wall. Thus, it means that the fuel was evaporated only locally in the area of the tin wall heated by the flame.

To obtain the fuel burning, it was necessary to direct the flame of the gas burner at the white smoke, see Figure 8. A flame developed immediately in the tin, which means the white smoke over the tin is an air-fuel mixture. As can be seen in Figure 9 , no white smoke appeared during burning of the evaporated diesel fuel.

Because the experimental tin was not heated up during fuel burning, evaporation of diesel fuel was reduced. Flame heat was not sufficient to ensure evaporation of enough fuel. The flame became smaller and smaller and finally disappeared. The white smoke appeared over the experimental tin again due to flame extinction, see Figure 10.

Because the experimental tin was not heated up, reduction of the fuel evaporation was still continuing. As a consequence, there was less and less white smoke over the tin. Finally, the white smoke disappeared completely.

As shown in Figure 10, the evaporated fuel content in the white smoke is not sufficient to maintain the flame. Thus the fuel mixture in white smoke is too lean for combustion. However, there is enough evaporated fuel to form the white smoke over the tin. Within the framework of this simple experiment, all three conditions of fuel evaporation and its burning were achieved: Firstly: evaporation of the fuel results in the white smoke formation over the experimental tin, see Figure 7, which corresponds perfectly to the white smoke from the FOAH exhaust pipe at cold-start, see Figure 5 and also increased opacity in Figure 3 (regime: Start).
Secondly: diesel fuel burning inside the experimental tin with no white smoke over the tin, see Figure 9, which corresponds to minimum values of opacity at operating modes 0 to 9 , see Figure 3.

Thirdly: Cooling the experimental tin and subsequent reduction of the fuel evaporation results in flame extinction with white smoke over the tin, see Figure 10, which corresponds to white smoke from the FOAH exhaust pipe, see Figure 6, and also increased opacity in Figure 3 (regime: Stop).

Based on this simple experiment, there is only one regime without white smoke, i.e. fuel burning regime.

Based on this fact, to reduce the white smoke formation, it is necessary to reduce the phase with fuel evaporation and to achieve the flame in the combustion chamber as soon as possible. Thus, the duration of fuel evaporation using the glow plug should be reduced to a minimum, ideally completely eliminated.

\section{INVESTIGATION OF MEANS FOR WHITE SMOKE ELIMINATION}

As mentioned, the objective of this paper is to propose and theoretically investigate several means for elimination of increased emissions (and also white smoke) during both coldstart and switching-off regimes, as follows.

\subsection{HEATING UP THE COMBUSTION-AIR BEFORE ENTERING THE COMBUSTION CHAMBER}

The influence of the heated combustion-air (and thus the airfuel mixture) on an increase in the rate of combustion is already known. Many publications present results concerning a rate of combustion increase by means of increasing air-fuel mixture temperature, e.g. [7], [9], [10] and [11].

Heating up the combustion-air in a conventional $\mathrm{FOH}$ could be achieved e.g. by using one or more glow plugs. These glow plugs could be placed in between the combustion-air fan and entry into the combustion chamber, see Figure 1.

\section{COMBUSTION-AIR HEATING UP CAN INFLUENCE:}

a) Acceleration of the start of fuel-mixture combustion and increasing the rate of combustion.

b) Due to increasing the number of glow plugs and thus electricity consumption, it could cause premature discharge of a car battery in the case of repeated starts e.g. during sleeping of the crew in heated cabin.

c) Significant increase in reliability of cold-starts at very low ambient temperatures.

d) Shortening of duration of white smoke and increased levels of emissions during both cold-start and switchingoff. However, it will not be able to prevent the formation of white smoke. 


\subsection{HEATING UP THE DIESEL FUEL BEFORE ENTERING THE}

\section{COMBUSTION CHAMBER}

The influence of the heated fuel (and thus the air-fuel mixture) is very similar to combustion-air heating presented in the paragraph above. Fuel heating also causes an increase in the air-fuel mixture temperature and thus increases of the rate of combustion, as with the combustion-air heating described above. However, it is not so easy to heat the fuel because of its different characteristics compared to air. Heating of the fuel has to be performed very carefully, the fuel must not come into contact with red-hot heating elements. Also, the boiling temperature of fuel must not be reached (about $180^{\circ} \mathrm{C}$, see [12]) to avoid formation of bubbles in the fuel system.

An example of one electric fuel-heater is presented in Figure 11.

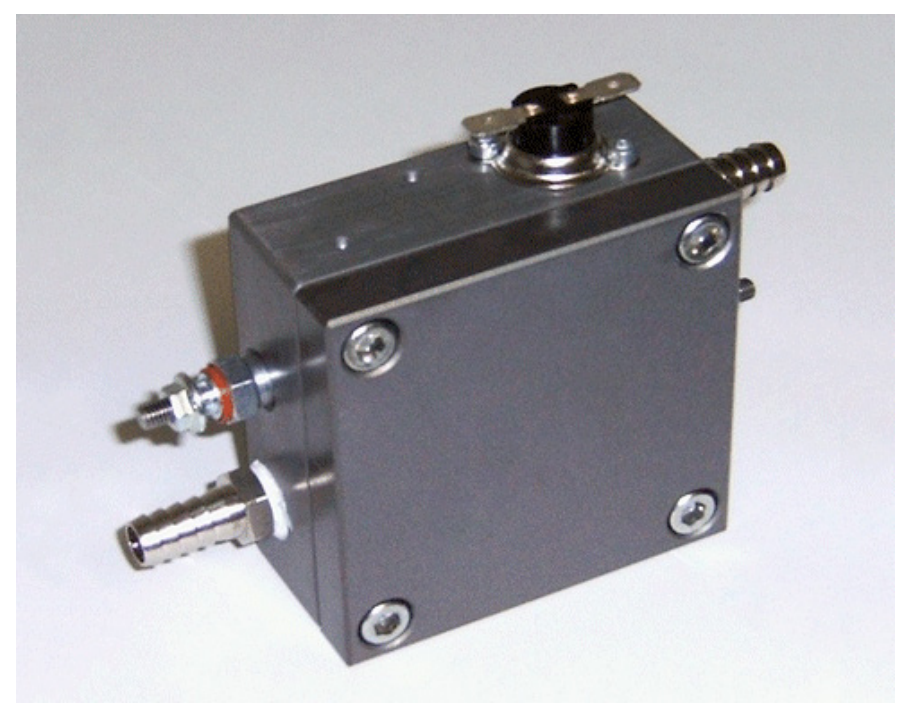

FIGURE 11: An example of an electric fuel heater, [13]. OBRÁZEK 11: Vzorek elektrického ohřivače paliva, [13].

\section{FUEL HEATING UP CAN INFLUENCE:}

a) As with the combustion-air heating, acceleration of start of fuel-mixture combustion and increasing the rate of combustion.

b) Increasing the number of glow plugs and thus electricity consumption. This could cause premature discharge of a car battery in the case of repeated starts.

c) Significant increase in reliability of cold-starts at very low ambient temperatures.

d) Shortening of duration of white smoke and increased levels of emissions during both cold-start and switching-off. However, it will not be able to prevent the formation of white smoke.

\subsection{ADDITIONAL HEATING UP OF THE COMBUSTION CHAMBER}

To shorten as much as possible the evaporation phase of the fuel and simultaneously white smoke formation, the combustion chamber could be additionally heated using e.g. another heat source (glow plugs). These additional glow plugs could be placed in the combustion chamber near the place where the fuel is evaporated and ignited, see Figure 1. The influence of the additional heating up of the combustion chamber could be very similar to heating up the combustion-air and also fuel, see the paragraphs above.

However, this proposed solution also will not be able to prevent the formation of white smoke.

\subsection{USE OF AN OXIDATION CATALYST IN THE EXHAUST PIPE}

Because a lean mixture (with excess oxygen) is combusted in the $\mathrm{FOH}$, only an oxidation catalyst can be used in the exhaust manifold to convert the $\mathrm{CO}$ and $\mathrm{HC}$ pollutants. The catalyst should be installed as close as possible to the $\mathrm{FOH}$ in order to secure its rapid heating up. In this way, the catalyst reaches its light-off temperature in a short time.

Using an oxidation catalyst in the $\mathrm{FOH}$ exhaust manifold has been already tested and it is described in work [2]. As described in this work, usage of the catalyst can eliminate increased emissions of $\mathrm{CO}$ and $\mathrm{HC}$, and also white smoke during $\mathrm{FOH}$ switching-off procedure.

However, increased emissions of $\mathrm{HC}$ and $\mathrm{CO}$ (also white smoke) during cold-start procedure have not been eliminated using an oxidation catalyst because of the low catalyst temperature.

To obtain a sufficient degree of both conversion of emissions and white smoke elimination using the catalyst during the cold-start, additional electric heating up of the catalyst could be applied. However, this means increased electricity consumption during the cold-starts, as in cases of combustionair heating up, described above.

An example of oxidation catalyst for $\mathrm{FOH}$ is presented in Figure 12, based on work [2].

\subsection{USE OF A HIGH-PRESSURE FUEL SYSTEM}

Based on work [1], a high-pressure fuel system consists of a fuel pick up tube, inlet fuel line, fuel filter, positive displacement rotary gear pump, fuel shut off valve, fuel nozzle, fuel nozzle heater and return fuel line, see Figure 13. The high-pressure fuel system is self priming and the pressure created by the pump (about 7 bar) is regulated by the system. The fuel flow is controlled by regulation of the fuel pressure in this fuel system. The use of this fuel system is limited to those systems with electrical arc ignition, [1].

An electrical arc ignition system is used in injection type diesel fired heaters, see Figure 14. In this type of system, the source of ignition is an arc rod system in which a high voltage (approx. 8000 volts) passes between two electrodes, [1].

Regardless of the ignition system used, its operation is limited to the first few minutes of each start cycle. Once combustion 


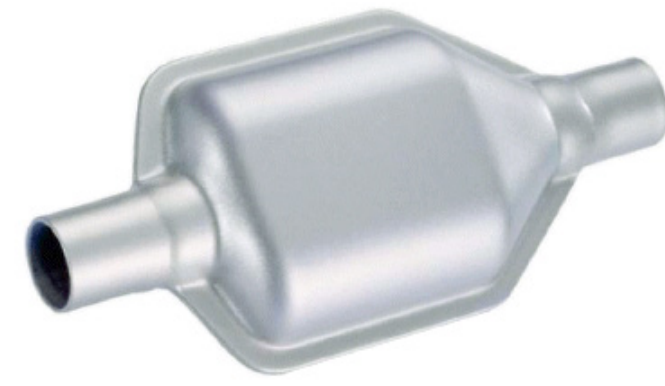

FIGURE 12: An example of an oxidation catalyst for FOH, [2]. OBRÁZEK 12: Vzorek oxidačního katalyzátoru pro naftové topení, [2].

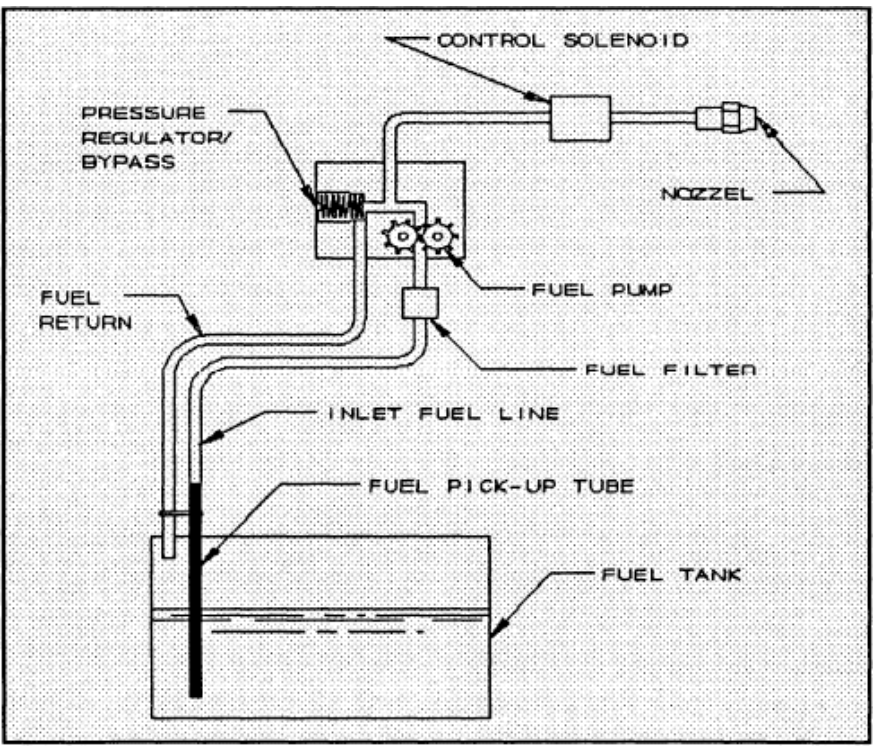

FIGURE 13: High-pressure fuel system of an FOH, [1].

OBRÁZEK 13: Vysokotlaký palivový systém naftového topení, [1].

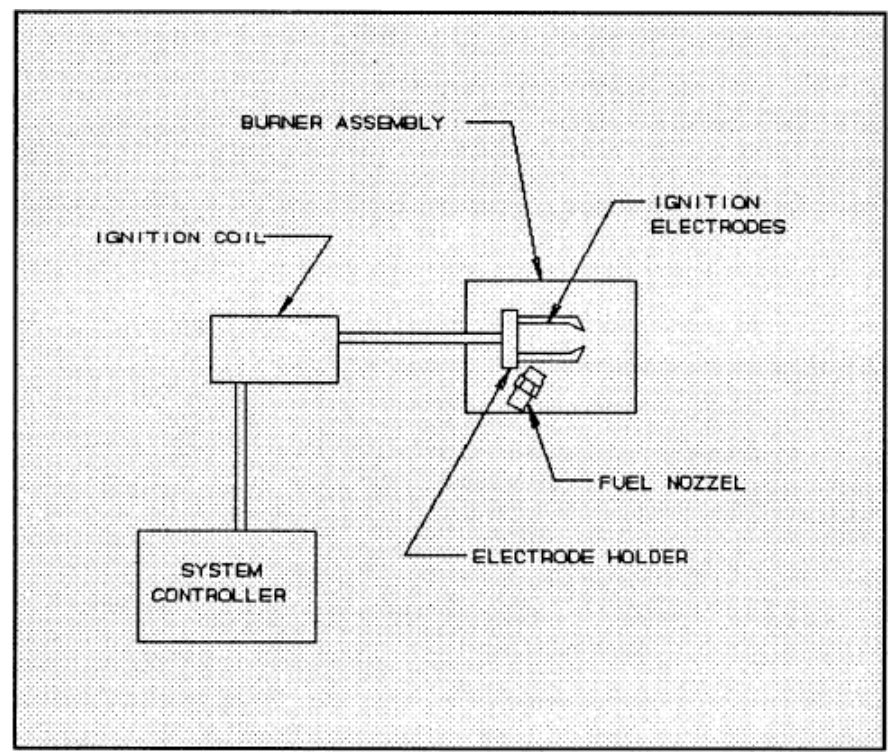

FIGURE 14: Electrical arc ignition system of a diesel FOH, [1].

OBRÁZEK 14: Elektrický zapalovací systém naftového topení, [1]. is established and recognized by the control system, the power of the ignition source is removed and the combustion process is self sustaining, [1].

Based on description of this fuel system above, it appears that it is able to create a flame in the combustion chamber immediately at cold-start without a phase of fuel evaporation. This means the phase of white smoke production during fuel evaporation, see Figure 7, is eliminated and there is only a phase with flame (without white smoke production), see Figure 9. The white smoke and increased emissions during the cold-start could be eliminated in this way.

Concerning the switching-off procedure, the high-pressure fuel system results in less fuel in the combustion chamber (compared to the low-pressure fuel system) that is evaporated without combustion after the fuel injection stops, see Figure 13. Thus, white smoke and increased emissions during switching-off could be reduced in this way.

\section{CONCLUSIONS}

This theoretical study is based on the experimental observation of white smoke formation, see Figures 7, 8, 9 and 10. Several proposed means were theoretically investigated in this paper (without experimental verification in a real $\mathrm{FOH}$ ) for their ability to eliminate the white smoke and associated increased emissions of $\mathrm{CO}$ and $\mathrm{HC}$ during both the cold-start and switching-off regimes.

Investigated proposed means:

Heating up the combustion-air, heating up diesel fuel and additional heating up of the combustion chamber are apparently only able to shorten the duration of the white smoke and associated increased emissions; moreover, they are very high energy consuming.

An oxidation catalyst placed in the exhaust manifold as close as possible to the $\mathrm{FOH}$ has great potential to eliminate increased emissions of $\mathrm{CO}$ and $\mathrm{HC}$ (also white smoke) during switching-off regime, if catalyst temperature is sufficient. However, its ability to eliminate increased emissions (also white smoke) at the cold-start regime is limited because of its low temperature. An additional heater upstream of the catalyst could be applied in order to increase the temperature of the catalyst before a cold-start. Nevertheless, such proposed means is also high in energy consumption.

High-pressure fuel system application seems to be a solution with great potential to eliminate increased emissions (also white smoke) during both cold-start and switching-off regimes. This system has the ability to create a flame in the combustion chamber without a long phase of evaporation of fuel from glow plug heating. 
Fuel is finely atomized using the high pressure of the fuel in the nozzle and an electric arc ignition system is applied for ignition of the air-fuel mixture.

However, some unburnt fuel (and associated increased emissions and white smoke) could appear in the exhaust gas during the switching-off regime even with high-pressure fuel application. Using an oxidation catalyst in the exhaust manifold could eliminate these mentioned increased emissions.

Based on the investigation described above, the best solution for elimination of increased emissions (and also white smoke) of diesel $\mathrm{FOH}$ at the both cold-start and switching-off regimes appears to be a combination of:

Using a high-pressure fuel system and simultaneously an oxidation catalyst in the exhaust manifold.

Note: The significance of start and stop emissions as part of the overall operational emissions of heaters can be very different due to various modes of use. In practice, the heaters can operate continuously for a very long time (e.g. in the case of heating of a very large passenger compartment under very low ambient temperature conditions). On the other hand, the heater can also operate discontinuously with a higher amount of starts/stops (e.g. in the case of heating of a small passenger compartment with good heat insulation, or under different ambient temperature conditions). Therefore, start and stop emissions could have a significant influence on the overall operational emissions.

\section{ACKNOWLEDGMENTS}

This research has been realized using the support of EU Regional Development Fund in OP R\&D for Innovations (OP VaVpl) and Ministry for Education, Czech Republic, project \# CZ.1.05/2.1.00/03.0125 Acquisition of Technology for Vehicle Center of Sustainable Mobility. This support is gratefully acknowledged.

This research has been realized using the support of Technological Agency, Czech Republic, programme Centres of Competence, project \# TE01020020 Josef Božek Competence Centre for Automotive Industry. This support is gratefully acknowledged.

This research has been realized using the support of BRANO GROUP, a.s., manufacturer of the independent air-heating system. http://www.brano.cz/.

This support is gratefully acknowledged.

\section{LIST OF ABBREVIATIONS}

CO Molar fraction of carbon monoxide [ppm].

FOAH Fuel-operated air heater.

FOCH Fuel-operated coolant heater

$\mathrm{FOH} \quad$ Fuel-operated heater.

HC Molar fraction of unburned hydrocarbons (Hexane) [ppm].

NO Molar fraction of nitric oxide [ppm].

THC Total Hydrocarbons

\section{REFERENCES}

[1] Kelling, G., Nelson, K. and Byrnes, B., Diesel Fuel Fired Heaters, SAE Technical Paper 922434, 1992, doi: $10.4271 / 922434$.

[2] Apfelbeck, R. and Barthel, F., Heating Comfort and Range Perfectly Combined-Heating Systems for Vehicles with Alternative Drive System. Prospects and Challenges of Biofuel-Operated Water and Air Heaters, SAE Technical Paper 2013-01-0240, 2013, doi: 10.4271/2013-01-0240.

[3] Polyakov, T., Y. and Valeev, K., D., Diesel Fuel Heaters for Arctic Vehicles, SAE Technical Paper 920035, 1992, doi: $10.4271 / 920035$.

[4] http://www.eberspaecher.com/, 2014.

[5] http://www.abb.com/, 2014.

[6] http://www.atal.czl, 2014.

[7] Miklánek, L., The Influence of Mixture Heating and EGR Delivery on SI Engine Efficiency at Part Load - Final Results. In: MECCA, 2012, Vol. 10, No. 1, pp. 28-37, ISSN 1214-0821.

[8] Takáts, M., Measurement of Emissions of Combustion Engines (in Czech). Czech Technical University in Prague, 1997, pp. 111. ISBN 80-01-01632-3.

[9] Macek, J., Combustion Engines I (in Czech), Czech Technical University in Prague, 2000, ISBN 80-01-02085-1.

[10] Brehob D., D. and Amlee, D., R., Effects of Inlet Air Heating and EGR on Thermal Efficiency of a SI Engine at Part Load, SAE Technical Paper 901713, 1990, doi: 10.4271/901713.

[11] Škarohlíd, M., Modelling of influence of Biogas Fuel Composition on parameters of automotive engines, SAE Technical Paper 2010-01-0542, 2010, doi: 10.4271/2010-01-0542.

[12] http://biom.cz/cz/odborne-clanky/etery-ziskavane-zbiomasy-jako-alternativni-automobilova-paliva, 2014.

[13] http://www.rostlinnyolej.cz/eshop/oh\%C5\%99ev-paliva/ p\%C5\%99edeh\%C5\%99ev-paliva-elektrick\%C3\%A1-24-vjednotka-detail, 2014. 